Chicago-Kent College of Law

Scholarly Commons @ IIT Chicago-Kent College of Law

February 2002

\title{
A Re-Evaluation of the New York Court of Appeals: The Home, the Market and Labor, 1885-1905
}

Felice J. Batlan

IIT Chicago-Kent College of Law, fbatlan@kentlaw.iit.edu

Follow this and additional works at: https://scholarship.kentlaw.iit.edu/fac_schol

Part of the Legal History Commons

\section{Recommended Citation}

Felice J. Batlan, A Re-Evaluation of the New York Court of Appeals: The Home, the Market and Labor, 1885-1905, 27 Law \& Soc. Inquiry 489 (2002).

Available at: https://scholarship.kentlaw.iit.edu/fac_schol/67

This Article is brought to you for free and open access by the Faculty Scholarship at Scholarly Commons @ IIT Chicago-Kent College of Law. It has been accepted for inclusion in All Faculty Scholarship by an authorized administrator of Scholarly Commons @ IIT Chicago-Kent College of Law. For more information, please contact jwenger@kentlaw.iit.edu, ebarney@kentlaw.iit.edu. 


\section{A Reevaluation of the New York Court of Appeals: The Home, the Market, and Labor, 1885-1905}

\section{Felice Batlan}

Closely examining a range of New York Court of Appeals police-power cases during the period 1885 to 1905 , this article demonstrates that the New York Court had a long history of accepting and continually expanding the police power. In these police-power cases, one finds the court grappling with an evolving sense of how to balance the concept of and need for a wellregulated society against the rights of an individual in an increasingly complex and interconnected world, as well as a tenacious refusal to abandon Victorian bourgeois norms regarding the dichotomy between the home and workplace. By contextualizing and historicizing New York Court of Appeals cases, the article challenges the dominant historiographical interpretations about late-nineteenth-century law. Moving away from a paradigm that labels the court conservative or liberal, formalist or realist, it argues that the court participated in creating a regulatory state while also employing a reasoning that adopted a sharp distinction between the market and the site of the domestic.

Felice Batlan is a doctoral candidate in the Department of History at New York University and an attorney. For their knowledge, time, and encouragement, my heartfelt gratitude to William E. Nelson, Thomas Bender, Linda Gordon, Richard B. Bernstein, Martha Hodes, and the participants at the NYU Legal History Colloquium. This article is part of a larger project that explores gender, the police power, and the politics of reform in turn-of-thecentury New York. 


\section{INTRODUCTION: A HISTORIOGRAPHICAL OVERVIEW AND METHODOLOGICAL INTERVENTION}

For almost a century, judges, lawyers, politicians, constitutional theorists, political scientists, and historians have debated whether courts from the late nineteenth century through the New Deal thwarted reform by striking down legislation as unconstitutional and importing an ideology of laissez-faire economics into the Constitution. ${ }^{1}$ Late-nineteenth- and earlytwentieth-century reformers, with few exceptions, viewed the courts as "scrooges" that obstructed their reform efforts by striking down legislation as unconstitutional and thwarting the creation of a welfare state. As historian William Ross observes, "Between 1890 and 1937, populists, progressives and labor leaders subjected both state and federal courts to vigorous and persistent criticism and proposed numerous plans to abridge judicial power"(Ross 1994, 1; see also Keller 1977, 358-70).

After the Supreme Court's Lochner decision in 1905, criticism of courts was unrelenting. ${ }^{2}$ At times, certain reformers viewed state courts as the primary culprits. Comparing state courts to the Supreme Court, the eminent political scientist Walter F. Dodd wrote, "[T] here remains the fact that perhaps the greater number of our state courts are illiberal and, under our present constitutional and judicial organization, are able to block needed social and industrial legislation" (Dodd 1913, 5).

One of the staunchest critics of the judiciary, Harvard law professor and dean Roscoe Pound, argued that the judiciary was out of touch with the new reality of an industrial America. Pound maintained that attorneys and the judiciary should turn to other social sciences, such as economics, when deciding cases to counteract the backwardness of law in meeting social ends (Pound 1912, 1905). On the eve of his appointment to the Supreme Court, Louis D. Brandeis lamented that judges were blind to the great social and economic changes that had occurred in the last 50 years and that such blindness caused them to write their own prejudices and conservatism into the law (Brandeis 1916, 464).

To a large extent, this understanding of the obstructionist role of courts in the postbellum period to the New Deal has dominated modern legal historiography and has shaped ongoing debates. The dominant thread of this historiography marked the scholarship of the Progressive era through the 1970s. Historians and scholars such as Charles Beard and Vernon Parrington continued the arguments of earlier Populists and Progressives and

1. Robert Wiebe writes that by the 1870 s a theory of full-blown laissez-faire was in effect whereby the poor would simply disappear, and government "above all did nothing to distupt the laws of free competition" (1967, 135). See also Paul 1960.

2. William Ross (1994) does an excellent job of mapping Populist and Progressive reactions to both state and federal courts, and this section draws on his research. 
accused the judiciary of enshrining private property rights as sacrosanct while opposing the regulatory efforts of state legislatures (Novak 1999, $9-10) .{ }^{3}$ Law and the courts were thus viewed as an obstacle to social reform, serving the interests of a capitalist class, frozen in an earlier age of individualism, and above all immensely conservative.

As William Novak writes, this theme with some flourishes and variations essentially continued through the 1960s (Novak 1999, 10-13). For instance, Sidney Fine's popular Laissez-Faire and the General Welfare State concluded that the judiciary was one of the staunchist supporters of laissezfaire and that they were "the ultimate censors of virtually all forms of social and economic legislation" (1956, 126; see also Jacobs 1954; Twiss 1942, Paul 1960). ${ }^{4}$ Although few contemporary historians present such a black and white picture of nineteenth-century law, the judiciary of the long nineteenth century is still often painted with broad brushstrokes as conservative and standing in the way of reform and certainly not as an active participant in the creation of the early welfare state. For example, historian William Wiecek claims that late-nineteenth-century law created a world where "all that was not forbidden was permitted; little could legitimately be forbidden" (Wiecek 1998, 97). Furthermore a great deal of more recent scholarship on late-nineteenth- and early-twentieth-century law focuses on a sharply drawn battle and distinction between legal formalism and legal realism, with legal realism gaining its real ascendancy only during the New Deal (see Hull 1997; Kalman 1986; Schlegel 1995; Horwitz 1992).

At the same time that one strand of scholarship asserts that courts thwarted regulation, another, at times less dominant, strand of scholarship argues that courts upheld a great deal of regulatory legislation. As early as 1913, Charles Warren, after reviewing cases decided by the Supreme Court between 1887 and 1911, concluded that the Supreme Court upheld the vast majority of legislation that was challenged. In the last decade and a half, a number of legal historians and constitutional scholars have seriously critiqued the idea that the courts adopted an ideology of laissez-faire. Instead, they argue, courts upheld a large majority of challenged legislation and primarily struck down legislation that was "class" or special-interest legislation. Such scholars argue that even when courts struck down reform-minded legislation, such decisions did not necessarily represent the adoption by courts

3. I owe an intellectual debt to William Novak, one of the article's reviewers, who relinquished his anonymity and provided insightful comments, as well as a copy of his ABF work, which contains an extremely valuable historiography of the rise of historians' characterization of courts as striking down legislation and upholding the idea of the laissez-faire state. Given that I have never directly communicated with Professor Novak, his generosity in sharing his ideas and research exceeds mere collegiality.

4. Even James Willard Hurst, who recognized the active role that law played in the nineteenth century in regard to furthering the release of energy principle and creating a dynamic economy, saw the late-nineteenth-century judiciary as essentially paralyzed (Hurst 1956, ch. 3). 
of laissez-faire economics but rather continued a long-standing jurisprudence requiring that legislation not benefit one class or special interest at the expense of another (see, e.g., Gillman 1993; Les Benedict 1985; McCurdy 1979,1975$).^{5}$

Much of this argument concerns the U.S. Supreme Court and centers on that court's Lochner decision. Indeed, Lochner seems to exercise a certain hypnotic fascination for many historians and constitutional scholars. As a corollary, few historians have focused intensely on the activities of state courts during the late nineteenth and early twentieth century. ${ }^{6}$ William Novak writes:

Beyond the ubiquitously invoked unholy trinity of laissez-faire constitutional cases E. C. Knight, In Re Debs, and Lochner v. New York, lies a largely unstudied, untapped mass of police, regulatory, administrative, corporation, utility, tax, eminent domain, health, insurance ... law that plays a crucial creative role in building the American liberal state. (Novak 1999, 43)

Yet even those legal historians who have examined the New York Court of Appeals in the late nineteenth and early twentieth century consider that court to be one of the most conservative in the country. ${ }^{7}$ The court received its reputation as a bulwark of conservatism from its decisions in a small number of cases in the late nineteenth century primarily involving labor legislation, and this analysis is essentially still the dominant view of legal historians of that court. Indeed, even as fine and meticulous a historian as Howard Gillman, who creates a brilliantly complex historical portrait of the U.S. Supreme Court, has written that before 1910 the New York courts struck down labor laws as class legislation (Gillman 1993, 145). William Wiecek goes even further and insinuates that the New York Court of Appeals was guided by an ideology of laissez-faire (Wiecek 1998, 127-28).

Not only is this view not entirely accurate in regard to labor cases, but also, by beginning and ending their analysis with such cases, some historians

5. As early as 1977, Morton Keller accepted Charles Warren's argument while also recognizing that the U.S. Supreme Court struck down significant legislation. Keller argues that the Court was torn between a backward-looking concern with private rights and individual freedom and a forward-looking concern with the development of a national economy (Keller Deal and argues that post-New Deal constitutional law, resulting in legal scholarship has greatly oversimplified pre-New throwing an older law order th an incorrect view of the late New Deal Court as overCushman 1998 for a revisionist accous hostile to regulatory laws (White 2000). See also

6. For a notable exceptist account of the Supreme Court during the New Deal. Scheiber 1984. Some of Scheiber'see Urofsky 1985. For a slightly earlier time period see conclusions that this article makes conclusions regarding California courts are similar to the

7. Edward S. Corwin makes regarding New York courts. constitutional law which have for their purk Courts have ordinarily pressed those doctrines of than the courts of almost any other jurisdiction" (Corwin 1917, 281). 
obscure the court's history of upholding other kinds of legislation. In the process they simplify a more complicated narrative of contestation, while at the same time obscuring the role of the court in creating an early regulatory state. Although cases involving labor were of enormous importance, at the time cases involving housing, child labor, and food were of at least equal importance and equally controversial. By focusing on one set of cases without addressing the others, legal scholars may have lost sight of the complexity of late-nineteenth-century law. We must see these other cases as different not in kind but rather in degree from the worker cases. Doing so allows one to theorize and understand the New York court's labor jurisprudence, along with that court's other police-power cases involving tenement housing, child labor, and food purity as part of a continuum that ebbed and flowed. ${ }^{8}$ Through an examination of the court's police-power jurisprudence in the years 1885-1905, this article shows that the court's dominant discourse was not the language of laissez-faire, with its embedded support of unconstrained capitalism and hostility to government regulation. ${ }^{9}$ Furthermore although defendants and their attorneys argued consistently that such

8. In 1917, Corwin undertook a review of New York cases decided between 1783 and 1905 that involved judicial review. He concluded that the New York courts struck down legislation at a considerable rate, finding that between 1881 and 1905, courts struck down or curtailed legislation in 213 out of 744 cases. A number of methodological problems, however, exist with Corwin's work. First, Corwin includes both lower court as well as appellate court decisions. Second, where the appellate court reversed the decision of a lower court that ruled a statute unconstitutional, it is still calculated in the numbers. In addition, decisions from multiple lower courts involving the same statute are counted separately. Third, cases that may have construed legislation narrowly are counted as striking down the statute. Thus, Corwin's statistical results may have double counted a number of cases. Most important for the purpose of this article, Corwin does not state why a statute was held to be unconstitutional. Thus, a court may have held a statute unconstitutional on very technical grounds that were easily rectified by the legislature. In other cases, the statute may have already been repealed by the time it reached the court, or the constitution may have been amended since the passage of the act. A 1952 work that examines judicial review in New York between 1906 and 1938 concludes that the courts generally upheld legislative exercise of the police power and that the "total count reveals seventy-seven acts upheld as opposed to seventeen pronounced invalid" (Smith 1952, 183). A much more recent analysis concludes that between 1870 and 1920 , New York courts invalidated 27 statutes on 24 subjects on the basis of the due process clause (Lindgren 1983, 596).

9. The article focuses on the time period 1885-1905 because many legal scholars believe that these years represent the height of a court-enforced laissez-faire regime, with the dominant form of legal reasoning being what is commonly referred to as formalist or orthodox legal reasoning. The analysis ends in 1905, the year when the United States Supreme Court decided Lochner $v$. New York. The New York Court of Appeals makes an interesting study since New Yorkers were particularly involved in the Progressive movement, a large number of immigrants were settling in New York City, judges on the court of appeals were elected, and some historians have viewed the court as particularly conservative. As William E. Nelson has written about his own work on New York courts, "New York was the most populous state and the economic and cultural leader of the nation. It was in one respect also more typical of the nation as a whole than any other single state: with its metropolitan center on the Atlantic coast, its upstate industrial cities ... and its rural farmlands" (Nelson 2001, 1-2). The cases that this article explores as examples of the court's police-power jurisprudence were chosen because of their novelty and way they advanced the court's thinking about the police power. With the exception of Francis Bergan's, The History of the New York Court of Appeals 
legislation was unconstitutional because it was class legislation that conferred benefits upon one class while disadvantaging others, the court repeatedly refused to find merit in such arguments, at times creating jurisprudential contortions to make such distinctions.

Although, this article ends with an examination of how the New York Court of Appeals decided Lochner, it does so only as a means to illustrate how situating that case within the larger context of police-power decisions of this leading state court helps us to recover the complexity of police-power jurisprudence before the U.S. Supreme Court's decision in Lochner. Further, the New York high court's handling of Lochner emerges most clearly when we examine the full range of arguments made by counsel and the reactions of the bar and the general public as well as the responses of the judges of the court of appeals. By shifting Lochner (in either its state of federal incarnation) away from the center of the inquiry, this article seeks to refocus attention on how the police power in New York developed within a frame quite different from the traditional scholarly focus on court decisions regarding the workplace and labor. Instead, using a new paradigm of analysis, this article seeks to demonstrate how the police power in New York developed within the conceptual site of the home; it shows how judges on New York's highest court used and reinforced an ideology that sought to separate the market from the home, and that used law to protect the home as a vital anchor of the well-regulated society.

As Amy Dru Stanley argues with respect to bourgeois postemancipation society, the home and the market were opposed to one another and at the same time mutually reinforcing. "[F]amily altruism counterbalanced ruthless buying and selling while free market relations nourished home life" through the wages of the male breadwinner (Stanley 1998, 170). In one way or another, the cases that this article examines conceptualized the home as the antithesis of the market. ${ }^{10}$ In deciding these cases, the court reified the special place of a noncommodified home while simultaneously upholding reform-minded legislation. ${ }^{11}$ Thus, as historian Eileen Boris postulates, state power could be used to maintain "homes as homes" as opposed to the monetized relations of the marketplace (Boris 1994, 100). Yet, this construction was inherently unstable, for to protect the home from the marketplace, the

1847-1932 (1985), there is little written about the court as an institution. Thus, how the fact the judges were elected to that court influenced its decision making is entirely unexplored.

10. For an in-depth discussion of the origins of the cleavage between the home and the marketplace as the household economy was replaced by wage labor that occurred outside of the hume, see Sklar 1973; Douglas 1977.

11. Daniel Rodgers argues that a "main thread" in Progressive thought was the desire to hold certain elements of life out of the market-to "de-commodify" them (Rodgers 1998, 29 . 30). The cases discussed in this paper are examples of such rationale, yet at the same time, in attempting to maintain sharp distinctions between the decomnodified home and the market, the Court was also looking backward to Victorian norms. 
court also regulated the marketplace, ultimately undermining the separation between them.

William Novak argues that from 1787 to 1877 courts upheld the vision of a well-regulated society in which safety, public space, morals, and the marketplace were regulated. He also maintains, however, that after 1877 , regulation of society became more problematic and courts were less willing to tolerate what Novak describes as the "ambiguous mess of substantive human and historical values" (Novak 1996, 247).12 The cases discussed here demonstrate that the New York Court of Appeals, at times vigorously, at other times hesitantly, maintained the tradition of a well-regulated society into the twentieth century, continually entering the fray of human affairs. Yet what Novak may have missed in his analysis by primarily examining what modern readers traditionally understand to be "public" sites is that a primary site at which the police power developed was the home. Thus, this article argues that a principal element in the court's inquiry whether to uphold legislation depended upon whether it looked at a case in connection with its affects on the domestic sphere or its affects on the market. Indeed, dichotomizing the home from the market was key to the judges' approach to police-power jurisprudence. In actuality, although the court did not see it this way, the two were opposite sides of the same coin. Legislation that affected the home also profoundly influenced the market.

At the center of the jurisprudential struggle over what constituted constitutionally permissible regulation stood the police power. Traditionally, the police power operated in that sphere in which the legislature could take action to promote the health, morals, and welfare of a society. Late-nineteenth- and early-twentieth-century "conservative" treatise writers, as well as some judges, argued for an extremely limited sphere of appropriate legislative action, enshrining the importance of free and unfettered liberty of contract and property. Freedom of property and contract meant for these legal actors the right to pursue any livelihood and to enter into any contract. For the legislature to interfere with property rights or freedom of contract was to violate the Fourteenth Amendment. Historian Kermit Hall writes that conservative treatise writers required legislatures "to steer clear of any regulatory efforts, and the courts, when legislatures did act, were bound to strike down laws as unconstitutional that violated the free use of property" (Hall 1989,222 ). In contrast, others interpreted the police power broadly and understood that pursuant to the police power, government could regulate and even destroy property. Thus, a great clash over what the police power meant erupted between conservatives and those who argued that such legislation should be upheld.

12. For an excellent review of the strengths and weaknesses of Novak's book see Scheiber 1997, 823. 
Among other things, this clash over the police power represented a profound enxiety over the growing interconnectedness of an industrial. urban society. All could agree with the great legal maxin that the police power, at a minimum, meant that one should use one's property in such a way as not to injure another's property. But what did this legal maxim mean in a world of growing and crowded cities where illness couid quickly spread, where propercy rights of one person could always affect another person, where the laborer's exhaustion and low pay could have far-reaching ramifications? As historian Robert $\mathrm{H}$. Wiebe writes, "As more people clustered into small spaces, it became harder to isolate the individual. As more of a distant world intrucled upon community life, it grew more difficult to untangle what an individual did and, what was done to him, even to distinguish the community itself from the society around it" $(1967,133)$. The police power became a principal site of conflict where the combatants explored and debated the questions of the interconnectedness of society and the law's response. It stood as a metaphor for the extraordinarily complicated question whether the effects of an individual's actions were private and outside regulation, or whether an individual's actions would always affect the greater community, and therefore lie within the sphete of legitimate regulation. Deeply embedded in this question was an anxiety about the homewhere it fit in an increasingly commodified society and how the police power could be used to preserve the home from the forces of the market.13

\section{THE TETEMENT CASES}

Historians debating the ideology of the New York Court of Appeals seldom discuss the New York City tenement cases. ${ }^{14}$ Nonetheless, the 1895 Trinity Church case (Health Deparment v. Rector of Trinity Church) and the 1904 Moeschen case are crucial to understanding the court's developing police-power jurisprudence and the role that both the market and the home played in its construction. Borh also serve as perfect borderline cases, because they implicated the public health, which traditionally fell within the police power, and more complicared class issues, as they pitted poor tenants

13. Although constitutional theorists and legal historians have usually recognized that the courts upheld legislation that protected the health, monals, and welfire of sciety, such formulation explains little about how judges made such Jeterminitions or what a court vould view as a valid police-power regulation that affected the entire community. Rather, the definitions of health, morals, and welfare are socially constructed and contingent, not a priori classifications. Indeed, a constant trope throuhour the police-power cases whe the question of who should decide whether a particular piece of legislation affected the health, morals, and welfare of a society, with those seeking to uphold the law anguing that such determination already had been made by the legislature and those seekng to stike down the law arguing that it was for the com to detemine.

14. Iawrence $M$. Frtedman is one of the few historians who menrions these decisicis in his examination of housing reform $(1967,30-36)$. 
against landlords. They also arose from laws primarily directed at New York City, which had experienced rapid industrialization, immigration, and urbanization. Yet as Daniel Rodgers writes, the internal dynamics of this "urban moment" of "revolt against laissez-faire" have not been fully explored (Rodgers 1998, 112-13). Furthermore, we must not dismiss these cases as "easy" because they concerned public health issues. Rather, the very question of what constituted public health was an unstable and disputed social construction. As the defendants continually argued, these cases were as much about the rental market, property rights, and class issues as they were about health. Indeed, public health cannot be separated from the market. Elizabeth Blackmar writes, "Manhattan's housing market developed above all else as a market in health" $(1995,52)$. The very sites where people chose to live reflected the ability to pay for a healthful environment that included access to clean air, water, and sewage disposal. Indeed, indoor plumbing was a class marker distinguishing the privatized family ensconced in a home entirely separated from their neighbors from the tenement dweller who shared a communal bathroom and water supply. Contemporary writers understood that issues such as sanitation for the poor were entirely intertwined with capitalist structures. As one journalist wrote in the Hebrew Trade Unions weekly Arbeiter Zeitung, "Capitalist society has become clairvoyant. It' knows its disasters. It knows their causes. . . . Today's capitalist society wants to get rid of these bacilli but without changing the living conditions of the poor. These ends cannot be achieved without such changes; they [contagion, poor sanitation, and] living conditions have grown up together" (Markel 1997, 123, quoting Arbeiter Zeitung).

Trinity and Moeschen also illustrate changing conceptions of property, as they deal with both traditional physical property interests and the expanding concept of dephysicalized property, in these cases taking the form of rental value. Thus they embody the clash between private property and public need. ${ }^{15}$ Inherent in both was also a pervading concern with the physical site of the home, how poor people lived, and the knowledge that the home itself had become part of the market, threatening carefully constructed dichotomies separating the home, the family, and the market.

\section{A. Trinity}

On the morning of February 27, 1895, readers of the New York Times learned, from a front-page article, that the New York Court of Appeals had upheld an 1887 law requiring the supply of water to each floor within tenement houses. With this decision, the Health Department of the City of

15. For a discussion of how cities in the late nineteenth century brought this clash of property rights and public welfare to the fore, see Rodgers 1998. 
New York won a hard-fought battle against Trinity Church, the landlord of numerous tenement houses (or, as the church called such buildings, "dwellings") throughout New York City. ${ }^{16}$ Although enforcement of the law had been sporadic, on March 20,1891, the Health Department served a summons on Trinity Church requiring it to renovate certain tenements by installing appliances to deliver water to each floor. The church was given five days to comply. The water supply for families at two of these tenements consisted only of a fire hydrant in the yard. To obtain water for cooking, house cleaning, and bathing, tenants had to carry water into their apartment in buckets or tubs. The literary pictures painted by journalists, of a communal water supply and dirty homes, clashed with the conventional images of the idealized, sanitized, and privatized middle-class family.

The New York Times had taken considerable interest in the story and made no secret of its support of the law. A month before the decision, the Times had run a long article when the city filed its legal brief with the court. The article gave the arguments for the city extensive space, with little discussion of Trinity Church's arguments. ${ }^{17}$ In the fall of 1894, the Tenement House Committee had publicized the condition of buildings owned by Trinity, and the Times had followed with its own investigation of the buildings, concluding that the buildings were unsanitary. As the Times opined:

If water is not easily accessible the poor will not avail themselves of its advantages. If it must be carried up two or three flights of stairs these people will not use any more than is necessary for drinking and cooking purposes. There will not be much scrubbing or washing done. It is entirely wrong that poor people should be subjected to such inconveniences to obtain such an essential to life and health. ${ }^{18}$

Trinity defended itself by publishing its own letter, mysteriously claiming that the Times had ulterior motives and citing another New York newspaper that praised Trinity as a humane landlord. The letter also claimed that the health law had "conferred upon the Board of Health summary and inquisitorial powers such as leave little rights to owners beyond holding title ... and bearing the burden [of being a landlord]."19

16. For a discussion of Trinity Church's property holdings see Day 1999; Blackmar 1989.

17. Brief against Trinity, New York Times, 13 Jan. 1895, 9.

18. Effect of the Decision, New York Times, 27 Feb. 1895, 1.

19. Letter from the New York Churchmen (Dec. 22, 1894) in the Trinity Church Report (Trinity Church $1895,3,5$ ). A number of times, the Trinity report quotes articles from the New York Observer that presented the church in a favorable light (see, e.g., 1895, 44). 
To modern ears, the need for indoor water is a truism. For contemporaries, however, it was not at all clear that the law would be upheld. As the comptroller of Trinity stated:

I am satisfied that [the law] was an extreme exercise of the police power. ... We determined that this decision had better be decided [by the courts], and we considered that it was more in the interest of the tenants, and a more sanitary rule not to have [the water] on all floors .... In many of the old houses the tenants are dirty and careless, and if there is water through the house they will throw all their slops in the sink.

The comptroller further stated that for $\$ 7$ a month tenants could not expect landlords to provide all modern amenities. ${ }^{20}$

The contemporary newspaper debate makes clear that this case was about the conditions in which the city's poor lived, thus arraying landlords against poor tenants. Landlords objected to the expenditure that would be required. Renovating plumbing would decrease profitability. It also pitted the property rights of landlords to do what they pleased with their physical property, against the public interest and the right of the city to regulate property ownership. The narratives produced by popular newspaper accounts created an irreconcilable conflict regarding capitalism. Trinity argued capitalism allowed the landlord the unrestricted ability to use his property as he chose. The Times implicitly argued that the proxy of the success of capitalism and free labor ideology was the clean, privatized home. To provide water would be to confirm the success of capitalism and free labor, as the essence of free labor was the right to have a clean orderly home separated from the marketplace. The legislation therefore did not threaten capitalism, but rather confirmed capitalism's ability to create the sanitized home.

At trial, the court found Trinity guilty of failing to provide water. On appeal, however, in a unanimous decision, the New York Court of Common Pleas reversed on the ground that the statute was unconstitutional. In hyperbolic rhetoric, the judges stated that the case concerned the gravest question of the "essential securities of property," and that the statute constituted a taking of property for private use, since it was "solely for the benefit of the tenants whom defendant is compelled ... to accommodate" (Trinity $1892,513)$. The court rejected the argument that the act was a legitimate exercise of the police power, finding it self-evident that there was no evidence that the lack of water on tenement floors affected the health of its occupants. The court further stated, "There is no necessity for legislative compulsion on a landlord to distribute water ... since, if tenants require it,

20. Effect of the Decision, note 18 above. 
self-interest and the rivalry of competition are sufficient to secure it" (Trinity $1892,515)$. As a final flourish, the court concluded with the following statement, worth repeating in whole:

The postulate upon which the legislation in question proceeds is the duty of government to exercise a paternal protectorate over the people; whereas the distinguishing characteristic of the American commonwealth is that it restricts the operation of government to the narrowest possible sphere; and reposes upon individual intelligence and effort for the development of a free and fruitful civilization. A conclusion contrary to the present decision would involve the essential principle of that species of socialism under the regime of which the individual disappears, and is absorbed by a collective being called the "state"-a principle utterly repugnant to the spirit of our political system, and necessarily fatal to our form of liberty. (Trinity 1892, 515)

The court's opinion combined the rhetoric of laissez-faire economics with the fear of class legislation and epitomized what legal historians identify as formalism. ${ }^{21}$ The court posited a binary opposition between public and private interests and implied that any legislation not equally beneficial to all members of a society was invalid. Furthermore, the court invoked laissez-faire economics as a foundation for its argument. If tenants wanted indoor water, they would either bargain for it with their landlords or move to a residence with indoor water. The legislation, therefore, was invalid and ineffectual, because it interfered with the invisible hand of the market. Finally, the court viewed the police power narrowly, refusing to grant any deference to the legislative decision that the lack of water raised health concerns. The court articulated the proper role of the state not as creating or maintaining a well-regulated society but rather as allowing the widest sphere for unfettered individual action. Indeed, any other role would lead to

21. Formalism, or orthodox legal thought, was a mode of legal analysis that viewed the law as a scientific, closed, and objective system of principles from which legal results could be logically deduced. This mode of thought (perhaps, discourse is the appropriate word) depended on abstract reasoning, often divorced from social reality, with courts increasingly resorting to higher and higher levels of generality. Formalist reasoning attempted to distinguish the judicial process--which merely discovered the law-from the political sphere where law was made. Formalists had an aversion to explicit analysis of policy and depended on legal categorization rather than factual analysis. Some legal historians have argued powerfully that embedded within formalism was the principle of laissez-faire economics, with its inherent fear of social engineering and dread of the potential for economic redistribution. Other historians argue that formalism was an attempt to relegitimate law after the overtly instrumentalist decisions regarding slavery, such as Dred Scott, that cast the legitimacy of the judiciary and judicial reasoning into doubt. There is a vast literature discussing the rise and fall of orthodox legal thought. See e.g., Wiecek 1998; Hull 1997; LaPiana 1994; Horwitz 1992; Kalman 1986; Nelson, 1982. Some historians such as Harry R. Scheiber have argued that such distinctions are overdrawn and that before and after 1860 , one finds a mix of judicial reasoning. Scheiber 1981. 
socialism and the destruction of the United States' political and economic system.

The court also articulated an absolutist concept of property. As property in the nineteenth century became dephysicalized, courts adopted such expansive views of property such that property became everything that had exchangeable value or expected earning power. As Morton Horwitz writes, "[D]uring the 1880 s and 1890 s a variety of new property interests for the first time received recognition by American courts. These property interests were endowed with what, by traditional standards, can only be called extravagantly expanded prerogatives. During this period, American courts came as close as they had ever had to saying that one had a property right to an unchanging world" (Horwitz 1992, 151). This is precisely the analysis that the court used, implicitly holding that there was a property right to the full amount of the net rental income on the building. Under this analysis, any required expenditure would constitute an illegal taking of property. Yet, to uphold this expanded right to property meant that the home itself was part of rather than exempt from the market.

On appeal to the court of appeals, the city took specific issue with the intermediate court's lack of deference to the legislative decision that the statute involved health. The city argued that it was not for the court to determine "the wisdom or folly of the legislation in question." Rather a court's role was to "determine whether the law has a 'tendency' to promote the public health." 22 The church countered that a court must determine substantively whether a law actually promoted the public health. The church further argued that "where legislation destroys or impairs the property of the citizen or interferes with his rights, it is void, unless it is for the public good, not merely for individual ease and comfort, or the benefit of one class." 23

As framed by the litigants and the lower court, three important questions emerged. First, what was the correct level of judicial deference to legislative decisions? Second, did regulation that required a positive expenditure of funds constitute an uncompensated taking of property by the state in violation of the Constitution? Third, who composed the public and could a police-power regulation be used to benefit some part of the population-in this case residents of tenements - at the expense of landlords? Had the court of appeals wanted to avoid these issues, it could have done so easily by upholding the regulation on the grounds that it constituted a fire regulation by requiring water on floors to extinguish small fires. Fire regulations were inarguably within the domain of the police power. Instead, the court of

22. Appellants Brief, Health Department v. Rector, Church Wardens of Trinity Church, New York Court of Appeals Records 13 (1895): 6.

23. Respondents Brief, Health Department थ. Rector, Church Wardens of Trinity Church, New York Court of Appeals Record 13 (1895): 13. 
appeals addressed these more complex, wide-reaching, and difficult questions. ${ }^{24}$

With one dissent, the court of appeals reversed the intermediate court's decision. The court framed the constitutional limit upon the police power as one that must "tend in a degree that is perceptible and clear towards the preservation of the lives, the health and morals or the welfare of the community. ... The court must be enabled to see some clear and real connection between the assumed purpose of the law and the actual provisions thereof' (Health Department $v$. Rector, 1895, 35; hereinafter cited as Trinity 1895). Thus, the court's definition of the proximate nexus between the legislation involved and its ability to promote health struck a middle ground between no deference and complete deference to the legislature.

The court then postulated that legislation requiring a property owner to make an expenditure was constitutional as long as the expenditure and the improvements required were reasonable. Thus, in 1895, the court adopted a very modern balancing test. Police powers, the opinion stated, must be examined by balancing the cost and difficulty of an improvement against the benefit of that improvement. The court further set forth its view of property, stating, "There are sometimes necessary expenses which inevitably grow out of the use to which we may put our property, and which we must incur, whether voluntarily or else under the direction of the legislature" (Trinity 1985,42 ). Hence, the court rejected a notion of property as a set of unchanging rights, rather holding that property is subject to reasonable regulation. As the court stated, quoting the words of Oliver Wendell Holmes, Jr., the difference between an unconstitutional taking and a constitutional regulation "is a matter of degree and not of kind" (Trinity 1985, 42). This balancing test, which Morton Horwitz recognizes as one of the important contributions of Progressive legal thought, broke down differences of kind into differences of degree. As Horwitz writes, judges who used a balancing test saw "the world not as a series of mutually exclusive black-white bright-line boundaries requiring intellectual on-off switches but rather as a series of continua involving shades of gray requiring line drawing" (Horwitz 1992, 18-19). By adopting this reasonableness test, the court rejected an analysis that depended on abstract categories of property and recognized that it would be required to draw lines. Thus, the court found that in this case the expense required to furnish water was reasonable, given the legislature's determination of the importance of water to promote health. Yet, there was no evidence introduced at trial as to whether water delivered to tenement floors protected health. Rather, the court based its decision upon

24. Interestingly, in a major treatise on the police powers published between the intermediate court's and the court of appeals' decisions, the treatise writers stated that "it was by no means evident" that the court of appeals would uphold the lower court's decision in Trinity. The treatise stated that a court must find a real and substantial relationship between legislation and its health effects. See Parker 1892, 7. 
its own construction of what the home and family life should resemble. (Interestingly, the court specifically concluded that it would be unreasonable for the legislature to require a tenement to have every amenity that a hotel provided, such as bathtubs or toilets. Ten years later, the Court was asked to decide just such a question.)

The Trinity decision earned mixed reviews from the bar, which believed that the case represented an expansion of the police powers, which indeed it did. As one New York Law Joumal article pointed out, "the same reasoning [that the Court used] would support, as a valid police regulation, almost any form of stepping stone of private convenience to an improved public moral or physical welfare."25 Trinity, however, was not just an expansion of the police power. Rather, it also embodied the proposition that the court would give substantial weight to a legislative determination that a particular statute benefited the public health and that the public could include only a particular class of people. Finally, Trinity endorsed and underscored that private property was subject to regulation, and that such regulation could decrease an income stream and require a positive expenditure of cash without violating the Constitution.

\section{B. Moeschen}

If Trinity was, to some extent, fought out in the press, then the Tenement House Department of New York v. Moeschen (hereinafter cited as Moeschen 1904) was truly a no-holds-barred court battle. Moeschen demonstrates the expansion of the police power during the ten-year period following Trinity and the court's replacement of a burden-benefits balancing test by its outright acceptance of the legislative determination that a statute benefited public health. Although chronologically separated by ten years, it is useful to view Trinity and Moeschen together, because they both concern tenement reform and because they reveal the court's expansion of the police power over this ten-year period, its increasing deference to the legislature, and its understanding that the home was to remain separate from the market.

In 1900, the Tenement House Commission was formed by the governor of New York to study the health issues of tenements and to draft possible legislation. In 1901, the commission submitted its report and found that school sinks posed a serious danger to the occupants of tenements and their neighbors. School sinks were outhouses with toilets that did not flush. Rather a valve would be opened, allowing water to rush into the bottom of the toilet, where matter collected, to flush it out. Some school sinks were not cleaned for weeks at a time, not only creating horrendous odors but also

25. Health Department of New York against Trinity, New York Law Joumal, 1 March $1895,1346$. 
attracting flies that could then spread germs. In the early twentieth century, there were more than 9,000 school sinks in tenements in New York City.

The commission recommended that all school sinks in tenements be removed and replaced with water closets, either in yards or indoors. In 1901, the legislature passed the Tenement House Act, which broke new ground in requiring that tenements have windows, proper ventilation, and toilets. ${ }^{26}$ The law required that all school sinks be removed, that each site be properly disinfected, and that one water closet be supplied for every two families. This new law reversed an 1870 law requiring that privy vaults be replaced with what were then believed to be more sanitary school sinks. As historian Morton Keller has noted; "This new law served as a model for a multitude of other state and local housing laws" (Keller 1990, 174). The renovations that the law required were so extensive that landlords of many tenements chose to tear the buildings down rather than attempt the renovations. Furthermore there is some evidence that, while the law allowed water closets to be built outdoors, this option was all but impossible given New York City weather conditions. Thus, the practical effect of the law was to require indoor water closets.

In 1903, Katie Moeschen received a summons for failure to remove school sinks in a building that she owned. The former owners of Moeschen's building had installed the school sinks to replace privy vaults as required by the 1870 law. Although it is unclear why Moeschen was chosen as a test case, it is clear that hers was a test case financed by real estate owners (see Deforest and Veiller 1903, xvii). Perhaps Moeschen was chosen because her school sinks seem to have been kept relatively sanitary and she was a small landlord, holding only one building. ${ }^{27}$ Indeed, Mr. Moeschen was a plumber and he testified to flushing out the school sinks personally every 24 hours. For whatever reason Moeschen was chosen, the real estate owners association spared no expense, demonstrating the importance of this law to landlords. At trial, numerous highly credentialed health and building experts testified about the merits of school sinks. On appeal, Moeschen's briefs were expertly argued and ran more than a 100 pages. The amount of time, effort, and money devoted to the case indicates that this was not an easy case but one that was highly contested and of great importance to tenement landlords.

Moeschen's attorneys argued that the law was unconstitutional because it deprived landlords of property by requiring the destruction of school sinks and the expenditure of funds to build other facilities. Such renovation 1962.

26. For a history of the 1901 act and the sordid politics behind its passage, see Lubove

27. Unlike other tenement owners, Moeschen did not engage in the process of subleasing the building to a lessee who was responsible for managing the building and collecting rents. Because the lessee was paid from proceeds, subleasing created some of the worst tenement abuses. See Day 1999, 47-50. 
would have the effect of reducing net income. They also claimed that the law was ex post facto, because it explicitly repealed a previous law requiring the installation of school sinks. Although this might sound like a particularly strange argument to the modern ear, historian Michael Les Benedict has written that laws that abridged vested property rights were particularly abhorrent to courts (Les Benedict 1985, 324). In fact, throughout the trial and appeals, Moeschen's attorneys continually emphasized this argument.

Learning a lesson from Trinity, the defendant further sought to prove that the cost of compliance was unreasonable and that the law did not protect the health or welfare of tenants. ${ }^{28}$ Finally, because the law applied only to certain cities within New York State, Moeschen's attorneys argued that the law was unconstitutional since it affected landlords in different cities differently making it class or special legislation. ${ }^{29}$

After losing on both the trial and intermediate court levels, Moeschen appealed to the New York Court of Appeals. Moeschen's brief was the embodiment of laissez-faire theory, social Darwinism, and formalist rhetoric. Moeschen's attorney argued, "Cleanliness is a matter of evolution. You can lead a horse to water but you can't make it drink. When the average tenement house dweller awakens to the advantages of cleanliness his physical and financial well being will have improved, and even as demand causes supply, the school sink will disappear by itself." Finally, the defendant stated, "This court is not ready to lay down the communistic proposition that the legislature may, at the expense of certain citizens promote or im-

28. At trial, Moeschen put on testimony regarding the unreasonableness of the expense that she would have to incur to comply with the law. Moeschen had paid $\$ 16,500$ for the building and carried a mortgage of $\$ 13,000$ with equity of $\$ 3,500$ and yearly net income of $\$ 300$. Moeschen's witnesses estimated that the cost of replacement could run $\$ 1,700$. The judge remarked that citywide the cost of replacement could run $\$ 20$ million. Trial transcript, Tenement House Department v. Moeschen, New York Court of Appeals Records, 50 (1904): 25. If Moeschen's testimony was truthful, the investment rate of return was $8.5 \%$. The rate of return that most tenement landlord's expected was 10\%-30\%. See Day (1999) for a discussion of tenement owners' rate of return.

29. At the conclusion of testimony, Moeschen's attorneys moved that the charges against her be dismissed on the ground that the statute was unconstitutional. In a strange twist, the judge denied the motion, stating that the question of the law's reasonableness, and hence of its constitutionality, was a jury issue. As the judge stated, "I appreciate perhaps if I were a Court of greater jurisdiction and not the local Court, that a more serious question would be presented to me, but the interests are vast and I do not feel that sitting here in a local Court $I$, in the first instance, with a jury empaneled, should determine a law unconstitutional." Trial Transcript, Moeschen, New York Court of Appeals Records, 50 (1904): 172. This is truly a remarkable statement. For at least a century, it was a widely accepted legal principle that whether a law was constitutional was a legal issue to be decided by a judge, and not a factual issue to be decided by a jury (see Horwitz 1977). Here, a court was specifically stating that the jury, rather than a judge, should decide the constitutionality of a law. In the judge's charge to the jury, he instructed that the jury was to determine whether the law was within the police power of the state by determining whether the law was reasonable and necessary to promote the public's health and welfare. The judge further instructed that, as a matter of law, legislative action must be "presumed reasonable" and that the burden is on the defendant to "throw off" the presumption of reasonableness. The jury, he instructed, was to decide the reasonableness of the law as a whole and not in just the specific case before them. 
prove the health of certain inhabitants." 30 Thus, appellants insinuated that, if just left alone, the invisible hand of the market would take care of all social problems. To interfere with the market was not only class legislation and communistic, but useless. Social legislation could not help the poor, because to be poor was a character trait. Only through the unfettered working of the market could the poor be elevated. If the court of appeals had wanted to rule in favor of Moeschen, it certainly had the language, the trial evidence, and the arguments to do so.

Unanimously, the court of appeals upheld the statute. In a relatively short opinion, the court held that the statute clearly promoted the general health and was therefore a proper exercise of the police power. The court refused to analyze substantively whether school sinks actually promoted the health of tenement dwellers. Instead the court, with minimum analysis, adopted the legislature's determination that it did. The court also stated that the financial burden placed upon an individual was irrelevant, given that "it is not the hardship of the individual case that determines the question, but rather the general scope and effect of the legislation." Thus, the court specifically elevated the welfare of the public over any hardship caused to an individual's property interest-a significant departure from Trinity, in which the court was specifically willing to balance the burden to the landlord against the benefit to the community. As to the tricky question of the ex post facto quality of the law, the court simply refused to recognize a distinction between a law requiring a building to be built to certain specifications and a law requiring alterations to a building already in existence, implying, rather, that both kinds of laws were points on the continuum of reasonable police-power legislation. Finally, the court, without explanation, refused to find that the law violated the Fourteenth Amendment because it applied only to tenements in certain cities and not in others. ${ }^{31}$

The court's opinion demonstrated again that it was unwilling to draw bright-line rules or engage in abstract reasoning to determine the particular outcome of a case. Rather then categorize the issue of one as property rights that cannot be destroyed, the court looked into the purpose of the statute and recognized that property rights were not absolute, but could be regulated and even destroyed for the benefit of the community. Moeschen also represented a move toward greater deference to the legislature from the court's position as enunciated in Trinity. The court had decided Trinity on the issue of reasonableness and had used at least a theoretical balancing test between the benefit of the legislation and the burden placed on landlords. In Moeschen, the court simply adopted the legislature's reasoning, showing

30. Appellant's Brief, Moeschen, New York Court of Appeals Records, 50 (1904): 90, 94.

31. Moeschen eventually appealed the decision to the U.S. Supreme Court. The Supreme Court upheld the New York Court of Appeals decision without issuing an opinion. Tenement House Department v. Moeschen, 203 U.S. 583 (1906). 
significant deference to the legislature. Trinity and Moeschen together illustrate the expansion of the police power and the court's increasing unwillingness to view any aspect of property as standing outside the sphere of regulation.

Likewise, neither of these cases fit within the current paradigms that scholars have constructed. Although defendants argued that the court should adopt laissez-faire principles and that such legislation interfered with the market and was therefore unconstitutional, the court refused to find merit in such arguments. Furthermore, both defendants argued that such legislation was class legislation because such laws only benefited tenants at the expense of landlords and because they only affected tenements in New York City. Yet, the court refused to find that such legislation was class legislation.

In addition, defendants' counsel in both cases argued that if tenants wanted the benefits of such legislation they would bargain for it as in any other contractual arrangement in the marketplace. Many historians have explored the sacrosanct nature of contracts in the nineteenth century. Yet, these cases presented dueling ideologies pitting the right to enter freely into contracts and the property rights of the landlord against the domestic sphere of the home, which supposedly stood outside of, and was unscathed by, the realm of the marketplace (see Hartog 2000; Stanley 1998). In postemancipation society, not only was the home supposed to be "uncommodified," but by the last quarter of the nineteenth century, the sanitized home was a virtual obsession, becoming a marker of what constituted an Americanized home where the temperate and industrious family dwelled. ${ }^{32}$ Dozens of books and articles directed to a middle-class female audience provided ever-more-detailed instructions for producing the spotless home. In Trinity and Moeschen, water, with its cleansing properties, and plumbing, which could instantly eliminate excrement, literally and figuratively had the ability to purify the home. By requiring the landlord to supply water, whether or not the tenement dweller bargained (paid) for it, the court protected the domestic sphere from the greed of the landlord and the commercial standards of the marketplace. The home could remain pure, uncorrupted by the marketplace and sanitized by water. The court thus proved itself willing to leave the free-contractual self standing at the threshold of the home, for the dichotomy between the home and the marketplace was a crucial component of the well-ordered and well-regulated society. ${ }^{33}$

32. For an excellent discussion of ever-rising cleanliness standards in the home, see Tomes 1998.

33. In fact, in a wide variery of cases involving building codes and an individual's community responsibility in the use of his or her individual property, the court of appeals repeatedly upheld legislation. See City of Rochester v. West (1900) (upholding law prohibiting the erection of biliboards more than six feet high); Village of Cathage v. Frederick (1890) (upholding municipal ordinance requiring property holders to remove snow and keep the sidewalk 


\section{CHILD LABOR}

New York v. Ewer (1894) is a case almost entirely neglected by legal scholarship, yet it was the first New York Court of Appeals case to discuss child labor; further it encompasses concepts of purity and reflects a particular view of what constituted an appropriate American family. Perhaps it is so neglected because legal historians view it as an "easy" case. Involving the constitutionality of a statute prohibiting child theatrical performances, the case can be understood as upholding a Victorian and Protestant sense of morality that fits easily within traditional police-power jurisprudence. Read another way, however, Ewer is a case about labor.

In 1893, Charlotte Ewer was arrested because of the activities of her daughter. Henry Stocking of the Society for the Prevention of Cruelty to Children, a private charitable organization with quasi-governmental power, had sworn out a complaint against Charlotte Ewer, charging that she violated a penal law prohibiting a person from exhibiting a female child under 14 as a dancer or in a theatrical exhibition. ${ }^{34}$ Mildred, Charlotte's 7-yearold daughter (who went under the stage name La Regaloncita), was appearing in a Broadway show, in which for approximately seven minutes she danced on stage. After being found guilty by a jury, Charlotte brought a writ of habeas corpus, in which she challenged the constitutionality of the statute, arguing that it infringed on her parental rights to the custody and services of her child. Ewer's attorney argued that Mildred was performing in a respectable theater in a legitimate theatrical play and that the law could not deprive a parent of her child's labor when such labor was not immoral. The New York Supreme Court rejected this argument definitively, stating, "The legislature's. . . determination that this is in the best interest of the state and of young girls ... is final, and is not subject to review by the Courts." ${ }^{35}$ Thus, in the lower court's understanding, it had no power to review policepower legislation.

clean); People ex rel. Kemp v. D'Oench (1888) (upholding law restricting the height of apartment buildings.); New York v. Rosenberg 410 (1893) (upholding law prohibiting fat rendering within New York City limits.). Although additional research needs to be conducted, at the end of the nineteenth century, zoning laws and the regulation of urban space began to be viewed as municipal housekeeping, and urban space an extension of the home itself. Historian Richard Bushman (1992) subtly begins to make this argument. On the role of women as municipal housekeepers in urban reform see Skocpol 1990. Daniel Rodgers argues that courts tended to strike down laws regarding aesthetic regulations and cites to Wineburgh Advertising Co. v. Murphy (1909) (Rodgers 1998, 203-4). As evidenced by the above cases, the New York court proved willing to uphold such regulations at the turn of the century.

34. The law also prohibited a male child under 16 from being exhibited. For a brief discussion of middle-class reformers' efforts to regulate child performers see Gordon 1988, 41 42.

35. Supreme Court Opinion, New York v. Ewer, New York Court of Appeals Records, 2 (1894): 18. 
On appeal to the court of appeals, Ewer's attorneys argued that the law was overly broad in that it did not require that a child actually be injured by a performance but rather imposed strict liability on parents for any theatrical exhibition of children. Ewer's brief argued further that a parent and child had the right to their own labor, the right to pursue an occupation, and the right to frame the plan of their lives. ${ }^{36}$ The state argued that the legislature was within its police power, because it had a significant interest in ensuring that children were educated to be good citizens. As the respondent's brief argued, "[B]oys shall, on arriving at maturity, be physically capable of bearing arms . . . and of intelligently exercising the elective franchise; and that girls, on becoming women, shall be so capable of discharging the maternal function and of educating their offspring." ${ }^{37}$ The state then listed the dangers to their health that child performers faced, which included fatigue, drafts, perspiration, and early death. It does not appear from the record that the state included any expert testimony or other evidence to support its claims regarding possible effects on children's health.

In a unanimous decision, the court of appeals upheld the statute. By doing so, the court was one of the first in the country to uphold a child labor law and embraced a stance of deference to the legislature regarding the police power. ${ }^{38}$ The court began its discussion of the police power by acknowledging that courts in the country were beginning to strike down legislation as unconstitutional and reaffirming its own belief in the ability of the legislature to regulate issues concerning the public's well-being. The court then ruled that the regulation of child labor was within the right of the legislature. In doing so, the court refused to examine whether, as a matter of substance, the law actually promoted the health of children. Rather, it ended its analysis once it found that the subject of children was within the discretion of the legislature. Yet the court was also concerned that, by upholding the law, it was being moralistic. To emphasize that it was not being moralistic, but rather showing due deference to the legislature, the court stated that the reason for upholding the law was "not the strict moralist's view, dictated by prejudice, but the view [of the legislature]" (Ewer 1894, 135). Thus, in Ewer, the court showed great deference to the legislature by refusing to review whether the legislation actually promoted the welfare of children.

Although contemporary legal historians might consider Ewer an easy case because it involved a strange interplay of child labor issues, morality, and fear of the sexual exploitation of children, contemporaries did not view it as easy. Indeed, discussing laws regulating child performers, historian

36. Appellant's Brief, Ewer, New York Court of Appeals Records, 2:21-22.

37. Respondent's Brief, Ewer, New York Court of Appeals Records, 2:6.

38. For a discussion of child-labor laws and the Progressive movement, see Keller 1990, 205-10; Davis 1967, 123-33. 
Linda Gordon writes, "Many groups resented its interference on this issuethe child performers, the parents who got their earnings, the impresarios who profited from theater, and the audiences" (Gordon 1988, 41). In particular, in 1882, the mayor of New York City provided special dispensation to allow a popular child performer to sing at matinees after a lower court had prohibited such performances. ${ }^{39}$ Labor historian Jeremy Felt specifically draws the connection between laissez-faire ideology and the inability of the state to legislate issues involving children (Felt 1965, 5). In the Ewer decision, the court rejected a laissez-faire approach to both the family and child labor. In doing so, it increased the sphere of those subjects construed to be within the domain of the police power.

Perhaps even more important, Elbridge Gerry, the attorney who argued Ewer, was one of the founders of the Society for the Prevention of Cruelty to Children, a controversial organization often described as interfering with the rights of the family. The society also continuously lobbied for child labor laws, including maximum-hours legislation for children, which legislators feared was the first step in a campaign to institute maximum-hours laws for adult workers. In the Ewer opinion, the court made an interesting, telling, and unusual remark. The court described Gerry as "able counsel whose earnest efforts in behalf of the cause of humanity and mercy have so distinguished him" (Ewer 1894, 133). Perhaps, one can read the court's remark as an endorsement of both child labor regulation and the rejection of any notion that as part of a laissez-faire ideology, the family and child labor could not be regulated. Indeed, in 1904, when a lower court upheld New York's compulsory education law, which prohibited the employment of children under the age of 14 during the school year, the court specifically cited Ewer as precedent (City of New York v. Chelsea Jute Mills 1904). Ewer, therefore, established a precedent of deference to the legislature in child labor cases and perhaps hinted that such legislation would be upheld.

Yet, child labor also directly implicated the idea of what constituted an Americanized home. As the court was so willing to hold, according to latenineteenth-century bourgeois standards, children essentially belonged in the home, not on stage. Indeed, Charlotte Ewer, who appears to have been a single mother, was imprisoned for her failure to maintain the appropriate family structure, which, according to reigning Victorian norms, should have at its core a male breadwinner upon which wife and children depended. Thus, Mildred's theatrical performances not only violated a sense of sexual morality, but also publicly and visibly commercialized a child while in-

39. In 1892, a New York legislative committee debated repealing the law. Numerous theater managers spoke, claiming that the law was without legitimate purpose, enforced arbitrarily, and prevented children from eaming a living. Such income, they claimed, was at times required to prevent a family from falling into poverty. Children of the Stage, New York Times, 14 Feb. 1892, 1. 
verting the proper sphere of both children and girls..$^{40}$ Ewer, which the court decided less than one year before Trinity, clearly pointed the way to the court's response in Trinity and became a case that attorneys and the court repeatedly relied on as precedent in the coming decade.

\section{THE FOOD CASES}

During the late nineteenth century, a profound interest in the purity of food products developed, spurred in part by a growing group of professional food hygienists inspired by Harvey W. Wiley, head of the U.S. Bureau of Chemistry in the Department of Agriculture. Food hygienists, as well as a number of prominent women from the growing settlement house movement and women's consumer organizations, campaigned to alert the public to the dangers of food adulteration. As Wiley declared, "What we want is that the farmer may get an honest market and the innocent consumer may get what he thinks he is buying" (Crunden 1984, 186; Keller 1990, 190-95). Thus, Wiley insisted upon honest labeling so that the health-conscious person could avoid injurious chemicals. The New York legislature, whether driven by concerns about protecting farmers from competition or about the health of the public, repeatedly passed laws enforcing food purity, and the New York Court of Appeals was called on to decide the constitutionality of such laws.

The court's decisions regarding food purity are important because they demonstrate that the court often deferred to the legislature's determination that the law promoted health. The court was also willing to uphold laws that were-as the defendant argued and one could reasonably concludespecial legislation in that they clearly benefited some industries and producers at the expense of others. Furthermore, food legislation directly affected the home, for in a real, material way it regulated what products would be allowed to enter the home and be consumed within it.

In 1889 , the legislature passed a law prohibiting the addition of coloring to cider vinegar. The law was passed to prevent distilled vinegar, which is white, from being marketed as cider vinegat, which is brownish. There was no health reason for preventing coloring, because the additive ingredient was unadulterated caramel. There is some evidence that the law was passed to protect upstate farmers, who distilled their own apple vinegar, from competition with vinegar manufacturers. Anthony Girard, an Italian

40. In 1883, the Society for the Prevention of Cruelty to Children had P. T. Barnum arrested along with the father of six children who performed a bicycle act in his circus. The trial court dismissed the case. Barnum then offered the SPCC superintendent $\$ 200$ to exhibit himself as "the man who wanted to take the bread out of those children's mouths" (Harris $1973,273)$. This episode demonstrates the unpopularity of such laws as well as the understanding that child performers provided a significant source of income for their families. It also perhaps points to the power of Barnum as compared to that of a single mother. 
immigrant who owned a small store in upstate New York, was found to have sold artificially colored vinegar in violation of the statute. Although there is no evidence in the record to indicate whether Girard was a test case, it would appear that someone paid his legal fees other than himself. ${ }^{41}$ The distilled vinegar manufacturers may have paid his costs, viewing the case as having an important affect on the industry.

The court of appeals upheld the statute, finding that it was within the police power of the legislature because it prevented frauds on the public. Yet at the center of the case stood the concept of the household and the notion of purity as distinguished from the corruption and greed of the market. Adulterated vinegar, corrupted by greed, became the physical agent that contaminated the pure home with the impurity of the marketplace. As the court wrote, "Everybody is familiar with cider vinegar, for it goes in all households." The court continued: "Food should be pure, absolutely and unquestionably pure." Likewise the court uncharacteristically blamed the state of impure foods in the home on the "greed" of manufacturers (Girard $1895,107)$. In the court's eyes, introducing impure vinegar into the home was not legitimate profit seeking but rather capitalism run amok. The court could have analyzed the case from the perspective of the manufacturer who was exercising his right to manufacture a product and contract with customers. Instead the court viewed the case from the perspective of the consumer and the product's point of contact with the home. The products that went into the household had to be pure, unadulterated, and free from the pollution and greed of the marketplace. The sanctity of the domestic sphere, in this case, trumped the property interest of vinegar manufacturers in producing their product as they chose.

Elizabeth Blackmar writes, "The creation of minimum housing standards came on the heels of the final deregulation of other markets (the inspection of food products, for example" (Blackmar 1995, 59). To the contrary, as Girard and a host of other cases demonstrate, the housing cases were not anomalies, and the court continued to uphold laws regarding food products. ${ }^{42}$ Indeed, it is crucial that the two types of cases be understood together in that both attempted to create the well-ordered home by supposedly cordoning off the marketplace from the home; in the process, the court participated in creating the well-regulated society.

41. Girard testified that he recently came from Italy and that he owned a small store and supplemented his income from other sources (New York $v$. Girard 1895, 107). It is doubtful that he could have afforded the legal costs of bringing the case to the court of appeals.

42. See New York v. Arensberg (1887) (upholding statute prohibiting the sale of any product not made from unadulterated milk or cream but made in imitation or semblance of dairy butter). See also New York $v$. Bowen (1905) (upholding statute that prohibited sale of milk that contained foreign substances); Crossman $v$. Lurman (1902) (upholding statute that prohibited sale of adulterated foods where damage or adulteration is concealed); New York ex rel. Lieberman $v$. Vandecarr (1903) (upholding statute requiring milk sellers to have a permit
from the board of health). 
Yet, the court did not uphold all food cases; rather it espoused the view that the legislature could regulate and even prohibit any article that it found to be dangerous to the health of the public; it could require labeling or prohibit a product that would deceive the public. The legislature, however, captured by a special interest, could not simply prohibit the sale of a product to protect one industry against another. ${ }^{43}$ As discussed below, the food cases shed light on the labor cases because they indicate the court's willingness to regulate products that touched the home, so long as such legislation did not entirely prohibit a person from engaging in such business. ${ }^{44}$

\section{ON THE ROAD TO LOCHNER: THE LABOR CASES}

Legal historians who consider the New York Court of Appeals conservative point to the court's hostility to labor legislation and view the court's position as one of laissez-faire. With this understanding, one must then view the New York court's Lochner decision as a temporary aberration. But, as demonstrated by the tenement cases, the child labor cases, and the food cases, the court did not endorse a laissez-faire ideology but rather was willing to view reform legislation, at least in those areas that affected the home, as necessary and constitutionally appropriate. Furthermore, the food cases demonstrate that the court did not necessarily endorse an unregulated market, but struck down legislation only when it appeared to have been enacted by the legislature solely to protect a certain segment of the market by driving another segment out of business. With this understanding, the court's labor cases begin to make sense, and the court's Lochner decision ceases to be an aberration in the court's police-power jurisprudence. When we analyze the labor cases by reference to the well-ordered home, with its emphasis on the roles of the male breadwinner and dependent wife and children who constituted a realm apart from the market, these cases take on more complicated and nuanced meanings.

One of the most notorious cases decided by the court of appeals was the 1885 case In re Jacobs. ${ }^{45}$ Jacobs was one of the first decisions in the country to strike down labor legislation and would forever brand the latenineteenth-century New York Court of Appeals as a haven of capitalism

43. There is quite a bit of evidence that rural upstate interests controlled the legislature, because the apportionment of seats in that body heavily favored such interests. See Kens 1990; McCormick, 1979.

44. This argument differs from those historians who argue that class legislation was particularly repugnant to the court since as already discussed both the tenement laws as well as the vinegar law could have been considered class legislation.

45. In re Jacobs (1885). In In re Paul (1884), the court had foreshadowed its disposition of Jacobs when it struck down an earlier law that prohibited tenement cigar manufacturing on technical grounds. 
and laissez-faire ideology. In 1884, the New York Legislature enacted as a public health measure a law, sponsored by Assemblyman Theodore Roosevelt, prohibiting the manufacturing of cigars in tenement houses. Peter Jacobs was arrested for violating this statute and imprisoned. Jacobs then was brought as a test case by the tenement cigar manufacturers, whom the law, if upheld, would have driven out of business. ${ }^{46}$ The New York Supreme Court first heard the case and ruled the statute unconstitutional, quoting at length from Adam Smith regarding the right of a man to own his labor.

The court of appeals affirmed the lower court's decision and found that the statute deprived Jacobs of his right to practice his trade, in which he had a property interest; the judges reasoned further that the law would put Jacobs in a dire economic position, requiring him either to rent a room, which he could not afford, or to work in a factory. In finding that Jacobs had a specific property interest in his work, the court adopted the broadest possible view of property, reasoning that any law that took away the value of property constituted an unconstitutional taking of property. The court approvingly quoted Blackstone's understanding of property as "the free use, enjoyment and disposal [of it] . . without any control or diminution" (Jacobs $1885,110)$. The court also adopted an exceedingly narrow view of its duty to defer to the legislature, stating, "It matters not that the legislature may in the title to the act, or in its body, declare that it is intended for the improvement of public health." Rather, the court found that "it is for the courts to scrutinize the act and see whether a statute is convenient and appropriate to promote the public health" (Jacobs 1885, 110). Thus, the court stated that it would review police-power laws substantively to determine whether they actually promoted the health of the public. The court then contrasted an invalid private law with a valid public law, and found that for an exercise of the police power to be valid, it must benefit the entire public, not just specific individuals. Because the cigar-manufacturing law benefited only tenement cigar makers, the court found that it was an invalid private law. Finally, the court found the legislation especially troublesome because it only applied to tenements in large cities, as opposed to tenements in all cities. ${ }^{47}$

Progressive reformer Jacob Riis described tenement cigar making as a particularly hideous industry. Tenement cigar manufacturing was a form of piecework in which landlord-entrepreneurs supplied tenants with tools, raw materials, and living space on credit, and the tenants as subcontractors made cigars in their rooms (Forbath 1985; Lindgren 1983). Often cigar manufacturing involved the entire family, including small children. Yet af-

46. William Evarts, a high-powered attorney and former U.S. attomey general and secretary of state, represented Jacobs. Other clients of Evarts included President Andrew Johnson. See Kens 1990, 61.

47. Although tenement cigar manufacturing was primarily concentrated in New York City, it did exist in smaller cities throughout New York State. 
ter an investigation of tenement cigar manufacturing, the New York City Board of Health concluded that conditions were not unsanitary and opposed the legislation. Surprisingly, Riis agreed, and concluded, from his own inspection of what were considered the worse tenements, that they were not unsanitary. Yet, according to Riis, cigar makers' entire families worked 12 to 16 hours a day to bring in pay that would barely cover the rent (Riis [1890] 1971, 109-13). To some extent, Progressive reformers, as well as the CigarMakers International Union (CMIU), saw the underlying problems of tenement manufacturing as a problem of child labor. Progressives worried that cigar making was injurious to children, and the CMIU found child labor disastrous to maintaining wages. ${ }^{48}$

If this is the case, a tremendous contrast exists between the court's analysis in Ewer and its analysis in Jacobs. In Ewer, which certainly involved child labor and was decided 10 years after Jacobs, the court specifically refused to go beyond the face of the statute to determine whether it actually promoted the health of children, instead accepting the legislature's determination that it did. ${ }^{49}$ Indeed, the court showed no hesitation with regard to regulating child labor and entirely prohibiting the child performer from contributing income to the family. A further contrast exists with Trinity and Girard. In Trinity, decided 10 years after Jacobs, the court had no trouble upholding a law that primarily benefited residents of tenements as a public law; moreover, it refused to accept a categorical and essentialist notion of absolute property rights. In Girard, decided 11 years after Jacobs, the court upheld legislation that clearly benefited farmers at the expense of manufacturers. Thus, Jacobs demonstrates either that, in the ten-year period following Jacobs, the court's police-power jurisprudence developed significantly, or that something else prompted the court's stern rejection of the law at issue.

Some legal historians have argued that decisions like Jacobs arose from residual antislavery arguments that privileged unregulated, self-ownership of one's own labor and the ability to use one's labor free from interference. ${ }^{50}$ According to these historians, courts were not engaging in deliberate selfdeception, but rather actually believed that one's capacity to labor was the

48. For a discussion of child labor and the effort at eliminating tenement cigar manufacturing, see Felt 1965, 10-13. For a superb gender analysis of cigar making, the cigar maker's unions, and Jacobs, see Boris 1991, 1994. This section draws on Boris's sophisticated analysis of the court's construction of masculinity and the home in Jacobs and the events leading up to passage of the legislation. Unlike Boris, however, who sees Jacobs as exerting a tremendous influence in the development of police-power jurisprudence nationwide, this article argues that the Jacobs analysis was within the decade abandoned by the court. It further seeks to place Jacobs within the context of other police-power cases.

49. When lobbying for passage of the act, Samuel Gompers did not seriously contemplate the possibility of its being struck down by the courts. In fact, looking at the courts of appeals record before Jacobs, he would have had little reason to believe that it would be struck down. See Forbath 1991.

50. For a discussion of free labor and the courts see Gillman 1993; Forbath 1991; Nelson 1982, 1988. 
essence of personal liberty and freedom. The Jacobs case provides considerable evidence for this view. In Jacobs, the court stated, "Liberty, in its broad sense as understood in this country, means the right, not only of freedom from actual servitude, imprisonment or restraint, but the right of one to use his facilities in all lawful ways, to live and work where he will, to earn his livelihood in any lawful calling, and to pursue any lawful trade or avocation" (Jacobs 1885, 106). In the picture that the court painted, the cigar maker was an independent artisan freely choosing to work from his home. The lower court's opinion found that the regulation "is so unjust in its inequality, so harsh and oppressive upon the labor of poverty, so keenly discriminatory in favor of the stronger classes engaged in the same occupation, that it certainly ought not to have been enacted" (Jacobs 1884, 383). But the language of free entrepreneurship contrasted greatly with the actual working conditions in the tenements. The court understood the cigar maker to be an independent laborer. Yet the reality of the cigar maker's working conditions was that he was not an independent entrepreneur, but an exploited worker. In addition to this tremendous conflict between the court's understanding of the nature of the cigar worker's conditions and the reality of them, something else seems to be troubling the court.

In 1877 , both factory and tenement cigar makers staged a threemonth-long strike in New York City, where more than 15,000 men and women cigar makers halted production. Although some accounts of the strike hailed the tenement workers as heroic strikers, the CMIU unjustly blamed the failure of the strike on the tenement workers and later refused to grant tenement workers membership in the CMIU as long as they worked in tenements. After the failure of the strike, the CMIU turned to the legislature to eliminate tenement manufacturing, which they believed undermined union efforts to raise wages in factories (Boris 1994, 32-39; Boris 1991, 125-32). An 1882 article in the Cigar Makers Official Journal complained: "Prices paid for cigars made in those pest houses are from $\$ 2$ to $\$ 6$ less per thousand than those made in factories. The tenement house system would have been abandoned long ago were it not for the European immigration which arrives daily.... There is a constant endless stream which unless checked will destroy us." ${ }^{51}$ In that same year, the socialist Cigar Makers Progressive Union was formed; it welcomed tenement cigar makers and campaigned for higher wages across the industry. After passage of the act, both the CMIU and factory manufacturers rejoiced; tenement manufacturers claimed that they would move out of the city and that workers forced to work in factories would now earn lower wages. Both the New York Times and the New York Tribune took schizophrenic views of the law, at times insinuating that the law's true purpose was to increase union control over the trade

51. Cigar Makers Official Joumal, 15 May 1882, 1. 
and force out the tenement manufacturers and at other times supporting the law. 52

Yet, it must also be remembered that Jacobs involved homework. Indeed, one would think that there would be no better case in which the court could have dichotomized market relationships from the home, as homework utterly collapsed the distinction between the marketplace and the domestic sphere. In fact, legislators who supported the bill did so based on the sanctity of the domestic sphere, arguing that the home should mean "privacy, decency, and morality" and that tenement manufacturing debased the family for "children failed to learn the difference between workshops and dwellings" (Boris 1991, 134). Work within the home corrupted the purity of women, children, and domestic space. Roosevelt condemned tenement work as preventing children and mothers from learning American ways. "American ways" of course meant that women and children did not work for wages and were dependent upon a male breadwinner. As Eileen Boris writes, "Homework . . . undermined American values and the home life behind those values, to which the family role of women was central. Tenement production was as alien as the immigrants who engaged in it" (Boris 1994, 22). Opponents of the bill constructed the nature of the home and the domestic sphere to mean that the state could not interfere in the private life of a man's home. They further argued that Jacobs, as a male breadwinner, had a natural right to his own labor and to employ it as he saw fit (Boris 1994, 39-41).

In striking down the law, the court adopted a strong paradigm of the male breadwinner, opining that cigar manufacturing allowed the male cigar maker to earn a living for his family. Moving its focus from producer to consumer, the court found that cigar smoking was a masculine pursuit crucial to the cross-class bonding of men and the performance of civilized masculinity. The court wrote that cigar smoking "has been in general use among civilized men for more than two centuries. It is used in some form by a majority of the men in this State, by the good and bad, learned and unlearned, the rich and the poor" (Jacobs 1885, 113). Thus, the court implied that the law threatened the freedom and masculine prerogatives of men of all classes by threatening the ideology of free labor.

In constructing the tenement worker as an independent entrepreneur rather than as a worker engaged in piecework, dependent on the labor of his wife and children, and beholden to the contractor, the court through a linguistic sleight-of-hand created the independent male breadwinner who sup-

52. Cigar-making in Tenement-Houses, New York Tribune, 14 Mar. 1883, 2; Men's Right to Work at Home, New York Times, 9 Feb. 1884, 8; Nominally the Purpose, New York Times, 2 Oct. 1883, 4; Cigar Act in Force, New York Times, 2 Oct. 1883, 2; The Act of the Last Legislature, New York Times, 7 Dec. 1883, 4. 
ported his family and through his labor constructed the home. ${ }^{53}$ This ideology was so strong that the court found the tenement cigar maker entitled to the appearance of the status of male breadwinner even when the appearance did not correspond to the reality. Thus, the cigar maker's property right was not only in his labor but also in the appearance of being a breadwinner. ${ }^{54}$ The decision allowed the court to preserve the autonomy of capitalists under the rubric that it preserved the autonomy of the laborer. The tenement cigar manufacturer who exercised his manly free labor was united with other free and civilized men who performed their status as such through the smoking of cigars. In Jacobs, the independent male citizen, free from government interference, and the paradigm of the male breadwinner in charge of the private sphere of the home necessitated the collapse of the distinction between the market and the home, for the very construction of the home depended upon the construction of the male breadwinner (see Boris 1994, 43-44).

Against this complex background, the court's decision in Jacobs takes on new meaning, and it becomes impossible and indeed simplistic to argue that the legislation was simply about protecting the worker and that the court's decision to strike down the legislation was merely an exercise in laissez-faire judicial activism. Rather, the legislation was about a complex interplay among unions, child labor, female labor, homework, factory work, the home, and the male breadwinner. Indeed, Jacobs was a case in which the imaginative pictures of the home and of the male breadwinner who achieved his status both through economic power in the realm of the market and through the exercise of paternalism in the domestic realm could not be reconciled.

Even if we accept the court's rationale that it was protecting the worker and the subtext that the legislation at issue in Jacobs was anticompetitive, within a period of 20 years the court would abandon the Jacobs mode of analysis. Cases involving labor would slowly begin to resemble other police-power cases. Each of the arguments found so compelling in Jacobs would, over time, lose their power to persuade. Thus, as compared with the other cases discussed here, Jacobs demonstrates a slow evolution in the court's police-power jurisprudence toward greater deference to the legislature. But, at the same time, historians have misunderstood Jacobs as a decision by a conservative court enforcing its vision of economic laissez-faire.

Ten years after Jacobs, the court of appeals decided New York $v$. Haunor, which had at its core an 1895 law requiring barbershops to be

53. As John Witt has argued, nineteenth-century courts in the area of wrongful death tort law consistently ignored the labor of wives and children and constructed a normative vision of the male as breadwinner with dependent wives and children. See Witt 2000.

54. One might conceptualize the court's reasoning as constructing a property right in white masculinity itself. For an argument regarding how courts constructed a property right to whiteness, see Harris 1993. 
closed on Sunday except in Manhattan and Saratoga Springs. Barbers in Brooklyn found the law particularly vexing because it did not require Manhattan barbershops to be closed, and Brooklyn barbers feared that they would lose clientele to Manhattan shops. Some barbers who did not own their own shops resented the law because they were now being paid for six days of work rather than seven. ${ }^{55}$ Given Jacobs, one would expect the court to have found the law unconstitutional, because it clearly applied to some barbers and not others and favored some cities over others. It also infringed on the concept so important in Jacobs, that one owned one's own labor and the ability of the male laborer to earn a living for his family. Indeed, Havnor's attorneys, following the reasoning in Jacobs, argued that the law "prevents [the barber] from carrying on a lawful calling as he wishes, and also of his property, by preventing the free use of his premises, tools and labor, and thus rendering them less productive" (New York v. Havnor 1896, 198). In a 4-3 decision, however, the court upheld the law. The court specifically denied that the law was a Sabbath law, pointing out that only barbering was regulated and that two cities were exempted. Rather, the court found that the law was a health law that protected citizens from overwork. Thus, the court held that the legislature may regulate work hours as a means of protecting workers' health. Again rejecting the idea that the law involved class legislation, the court specifically found without merit the argument that the act violated the Fourteenth Amendment because it did not apply to all barbers. Yet in Jacobs, the cigar-tenement law's application to only some cities provided a rationale for demonstrating that the act did not involve health at all. Likewise, newspaper reports indicate that the barbershop law was perceived as a penalty for Brooklyn's failure to support consolidation with the city of New York and as such could be viewed as a clear example of class legislation. The court refused, however, to see it that way.

Haunor, decided one year after Trinity, can be interpreted as an extension of Trinity, with its flexible notion of property and deference to the legislature, into the labor sphere. Because Hawnor involved Sabbath laws, the court may have been less hesitant to find the challenged measure within the police power. Yet at the same time, the court did not rest its position on the argument that the law protected the morality of the community, instead finding that it protected the health of the worker by requiring a day of rest. ${ }^{56}$ Hawnor, however, must also be viewed as involving the home. As

55. Brooklyn Is Wrathful, New York Times, 1 June 1895, 1. See also, The Barber Law Is Valid, New York Times, 15 April 1896, 1.

56. Equally inconsistent with Jacobs and in line with the other police-power cases is Nechamcus $v$. Warden (1895) in which the court upheld a statute requiring the state's certification of master plumbers. In Nechamcus, the court strained to find some benefit to society flowing from such legislation and explicitly stated that if legislation could be given any construction that could validate it as a legitimate exercise of the police power, the court must so construe the statute. Thus, the court refused to view the statute as a pretext for conferring monopolies upon plumbers with more experience. But see Tyroler v. Warden (1898) in which 
Ann Douglas writes, "Sunday was the one day of the week the American male was supposed not only to go to church but to stay home" (Douglas 1977,111 ). Douglas's examination of women's literature demonstrates that Sunday, more than a church day, was viewed as a day that the family gathered together in the home. If six days of the week were to be devoted to commerce, the seventh day was to be devoted to the home. The barbershop law not only prevented the barber from working but prevented men from frequenting such shops, which contemporary accounts indicate was a male gathering spot on Sundays, providing men an alternative to the home. As one newspaper recognized, men who went to barber shops on Sunday often became involved in discussion and failed to "arrive home until his dinner is on the table." 57 Thus again, if one looks at the law from the point of view of the barbershop consumer rather than that of the barber producer, one can see the ideology of the sacred space of the home at work.

By 1904, the year that Lochner was decided in New York, the police power had been firmly upheld in cases involving tenements, food products, zoning, child labor, Sunday laws, and environmental conservation, as well as numerous other areas. ${ }^{58}$ As this article demonstrates, the degree of scrutiny with which the court examined police power legislation became progressively less strict. By 1904, it appeared that the court would not examine substantively whether legislation actually promoted the health and welfare of the public. Furthermore, bright lines between categories of what constituted property had broken down, as had notions of public and private. As demonstrated in Trinity, the court was much more likely to see the interconnectedness of society, how one person's property or contractual freedom would have ramifications for society as a whole, when such consequences involved the home. Also by this time, the court had accepted that legislation could be class-based, burdening some and benefiting others. In the con-

the court stuck down a statute that prohibited the brokering of tickets on common carriers. Tyroler, to some extent, might be a pro-immigrant decision. Ticket brokers often played important roles in the immigrant community, acting as employment agents, travel agents, and quasi bankers. For a discussion of the role of Italian banchiere see Montgomery 1987, 76-77. For a general discussion of state professional licensing cases that argues that no general theory of economics can be found in such cases see Friedman 1965. An even more complex case is New York ข. Orange Conty Road Construction Company (1903), in which the court, using a Jacobs-type analysis, struck down legislation requiring that a minimum wage be paid to employees of all independent contractors engaged in state work. One year later, however, the court upheld a law requiring that the "prevailing wage" be paid to all laborers, workmen, or mechanics working on any public work, Ryan v. City of New York (1904).

57. Brooklyn Is Wrathful 1 , note 55 above.

58. Lawton v. Steele (1890) (court upheld statute that prohibited net fishing in certain waters); American Rapid Telegraph Company v. Hess (1891) (court upheld statute that required the removal of telegraph poles and found that telegraph company had no vested property interest in placement of such poles). 
text of this understanding, Lochner represented the zenith of the court's police-power jurisprudence. ${ }^{59}$

At issue in Lochner was a statute that set minimum sanitary conditions for bakeries, and prohibited bakers from working more than 10 hours a day under any circumstances. The history of the legislation is long and complicated. At the turn of the century, most bread bakeshops were small and had few employees. In urban areas, they often were located in the basements of tenement buildings in less than sanitary conditions. Workdays of 12 to 16 hours were common. In 1895, the bakeshop law was passed with a combination of Progressive reformers' support, a public campaign exposing the conditions in bakeshops, and union support. In April 1901, Joseph Lochner was charged with violating the hours portion of the act. ${ }^{60}$ On appeal, Lochner's attorneys essentially argued a position similar to that espoused in Jacobsthe absolute right of a person to own his labor free of regulation and the right to contract freely regarding its use. Lochner's lawyers also argued that the legislation was passed not as a health regulation but rather as a pretext for labor regulation.

The majority opinion of the New York Court of Appeals that upheld the statute was masterly, written in particular with an eye to convincing the Supreme Court of the statute's legitimacy. The opinion first clearly set out the standard that a court must use when determining the constitutionality of legislation, setting forth this standard as follows:

The courts are frequently confronted with the temptation to substitute their judgment for that of the legislative power ... and especially when the case is one on the borderline, it is quite possible that the judgement of the court that the legislation is unwise may operate to carry the decision to the wrong side of that borderline. Certain it is that the courts have greatly extended their jurisdiction over many administrative acts that were originally supposed not to present cases for the court to pass upon." (Lochner 1904, 167).

The court then called upon its long history of upholding police-power cases to demonstrate that a court must not strike down a statute if there is any way that it can be construed as constitutional. This articulation represented both a great amount of deference to the legislature and the culmination of the court's years of grappling with the police power. This standard of review, if viewed only in connection with Jacobs, represents a complete

59. The New York Court of Appeals' Lochner decision has been ignored by some historians because the decision was so eclipsed by the Supreme Court's decision. As argued in this article, the Lochner decision and its subsequent reversal is tremendously important in understanding the New York Court of Appeals police-power jurisprudence. 1990.

60. For an excellent account of the history of the passage of the bakeshop act, see Kens 
anomaly. Viewed, however, as part of a long line of police-power decisions, it represents the evolution of the court's reasoning.

Turning to the legislation itself, the court found that the well-rested baker was likely to be more careful and clean than the fatigued baker: "If there is opportunity . . . for this view, then the legislature had the power to enact it, and the courts are bound to sustain its action as justified by the police power" $(1904,165)$. Thus Lochner, even though a labor case, followed the same reasoning and analysis employed in the tenement cases, the food cases, and the Sunday-barbering case.

The concurring opinion by Judge Vann is equally informative. Judge Vann upheld the law on the grounds that bakers were subject to greater health risks than people employed in other occupations. The Lochner briefs, however, had not argued substantively whether bakers were at greater health risk and did not contain data regarding such health risks. Instead, Judge Vann appears to have done his own research on the relative dangers inherent in the baker's occupation, citing more than 20 different sources, including medical encyclopedias, dictionaries of statistics, industrial hygienists, and medical journals indicating that certain occupations, including that of baker, posed health risks. Thus, four years before Louis D. Brandeis's and Josephine Goldmark's famous brief in Muller v. Oregon, Judge Vann had already begun looking outside the law to scientific facts to determine a case. ${ }^{61}$ In doing so, the facts that he cited regarding occupational hazards left substantial room for the legislature to continue regulating a wide range of occupations.

Lochner has been treated primarily as a labor case. Yet Lochner was also about the products that went into the home, and, to some extent, the court of appeals treated it as such. By 1905, a majority of women had ceased baking their own bread and began buying premade bread. At the same time, the germ theory of disease had become widely accepted by laymen, and there was considerable fear that the contaminated loaf of bread would bring disease into the home. ${ }^{62}$ Thus, the loaf of bread made by the baker was a point of connection between the industrial and the domestic in which the industrial could literally contaminate the domestic. Unlike Girard, where the court could only employ tropes of the impure product entering the domestic sphere, in Lochner, the germ of the fatigued baker became the agent that could contaminate the home and family. Yet, in its recognition that the family ate the bread produced by the workman, Lochner represents a slight shift in the court's thinking about the home. No longer did the court view

61. Muller v. Oregon (1908). At issue in Muller was the constitutionality of a maximumhours law for women; Josephine Goldmark and Louis Brandeis submitted a brief on behaif of the National Consumers League to the Supreme Court that extensively cited social science research.

62. For a discussion of the development of germ theory and its acceptance by both laymen and professionals, see Duffy 1990, 193-203; Rosenberg 1987, 137-41. 
the domestic sphere as separate and apart from the marketplace, but rather the two formed part of a continuum for what occurred in the industrial sphere had ramifications within the domestic sphere. ${ }^{63}$ Thus, the court upheld the statute not solely because maximum hours aided the baker but also because the baker's health affected consumers. In doing so, it recognized the interconnectedness of the home and the industrial sphere.

As noted, Lochner marked the zenith of the New York Court of Appeals' police-power jurisprudence. Its analysis left little doubt that the legislature could constitutionally pass new regulation to fit the needs of a new society, whether or not such regulation interfered with traditional property rights or freedom of contract. For a moment in time, it appeared that the Jacobs decision had been all but overruled, and labor would be treated in the same way that more traditional subjects of the police power were treated. Yet the end of the story is already known.

In 1905, in an infamous decision, the United States Supreme Court overturned the New York Court of Appeals' Lochner decision and struck down the bakeshop hours legislation as a violation of the Fourteenth Amendment. In doing so, they gave a name to an era that would stand for court enforcement of laissez-faire capitalism and judicial interference with legislation. Interestingly, in the Supreme Court's decision, the discussion of the germ, the family, and the consumer are summarily dismissed and the baker (and his bread) is reconstructed as a lone individual unconnected to the domestic sphere.

In one of the first police-power cases decided by the New York Court of Appeals after the Supreme Court's Lochner decision, the New York court in Schnaier v. Navarre Hotel and Importation Company (1905) struck down legislation requiring each person in a firm employing a master plumber to be registered as a master plumber whether or not the individual engaged in plumbing work. The court stated that the Supreme Court's Lochner decision was "far reaching in its scope and effect" and stood for the "principle that the individual's right to make contracts in relation to business is a part of that liberty protected by the Constitution" (Schnaier 1905, 89). Lochner, to some extent, foreclosed the path that the New York Court of Appeals was following. Only more scholarly attention to the New York court as well as New York lower courts, will tell us exactly what effect Lochner had on the course of New York law in the early twentieth century.

63. Although additional research need to be conducted, this subtle change in the court's thinking may have been influenced by the atgument of women's organizations such as the National Consumers' League and the settlement houses, which publicized the argument that products produced in sweat shops could transport germs and contagion into the middle-class home. See, e.g., Boris 1994; Sklar 1995; Skocpol 1990. For the tole of women in creating a welfare state see Gordon 1990. 


\section{CONCLUSION}

The New York Court of Appeals' police-power jurisprudence during the years 1885 to 1905 does not fit neatly into the paradigm of courts consistently striking down legislation and substituting an ideology of laissezfaire while elevating formalist notions of the right to property and freedom of contract. Nor does it fit into the understanding that legislation that benefited a special class was struck down. Rather, the cases discussed here demonstrate that the well-regulated society identified by William Novak as reigning from the 1770 s to the 1870 s continued into the twentieth century and that the circumference of what constituted a legitimate exercise of the police power by the legislature was continually expanding. Equally important is a perspective that recognizes the importance of the domestic sphere and its relation to capitalism and free labor, for in a real and material way the New York court's police-power jurisprudence radiated in concentric circles from the domestic sphere to the industrial sphere. The development of New York's police-power jurisprudence was often complex and uneven, with attorneys, the lower courts, the court of appeals, the legislature, and the public in constant dialogue with one another about the role of the judiciary and the constitutional limits of the legislature.

Out of this dialogue came the Lochner decision, the high-water mark of the police power's reach in New York jurisprudence. At this point, however, the U.S. Supreme Court entered into the dialogue with a different understanding of both judicial power and what constituted a well-regulated society. Its decision eclipsed the contrasting doctrines of New York law for generations of historians and legal scholars. ${ }^{64}$ This is the most dramatic example of how the U.S. Supreme Court's jurisprudence has overshadowed the important history of the state courts and has lent a monolithic quality to American law, hiding the complexities and contestations that existed in the law of the long nineteenth century.

\section{REFERENCES}

Bergan, Francis. 1985. The History of the New York Court of Appeals 1847-1932. New York: Columbia University Press.

Blackmar, Elizabeth. 1989. Manhattan for Rent, 1785-1850. Ithaca, N.Y.: Cornell University Press.

1995. Accountability for Public Health: Regulating the Housing Market in Nineteenth Century New York City. In Hives of Sickness: Public Health and Epidemics in New York City, ed. David Rosner. New Brunswick, N.J.: Rutgers University Press.

64. See Reid 1995, who makes the same point with respect to judicial biography. 
Boris, Eileen. 1991. "A Man's Dwelling House Is His Castle": Tenement House Cigarmaking and the Judicial Imperative. In Work Engendered: Towards a New History of American Labor, ed. Ava Baron. Ithaca, N.Y.: Cornell University Press.

1994. Home to Work: Motherhood and the Politics of Industrial Homework in the United States. New York: Cambridge University Press.

Brandeis, Louis D. 1916. The Living Law. Illinois Law Review 10:450-75.

Bushman, Richard. 1992. The Refinement of America: Persons, Houses and Cities. New York: Knopf.

Corwin, Edward S. 1917. The Extension of Judicial Review in New York: 1783-1905. Michigan Law Review 15:281-313.

Crunden, Robert. 1984. Ministers of Reform: The Progressives' Achievement in American Civilization 1889-1920. Urbana: University of Illinois Press.

Cushman, Barry. 1998. Rethinking the New Deal Court: The Structure of a Constitutional Revolution. New York: Oxford University Press, 1998.

Davis, Allen. 1967. Spearheads for Reform: The Social Settlements and the Progressive Movement 1890-1914. New York: Oxford University Press.

Day, David N. 1999. Urban Castles: Tenement Housing and Landlord Activism in New York City, 1890-1943. New York: Columbia University Press.

Deforest, Robert, and Lawrence Veiller, eds. 1903. The Tenement House Problem, vol. 1. New York: Macmillan.

Dodd, W. F. 1913. Social Legislation and the Courts. Political Science Quarterly 28:1-17. Douglas, Ann. 1977. The Feminization of American Culture. New York: Knopf.

Duffy, John. 1990. The Sanitarians: A History of American Public Health. Urbana: University of Illinois Press.

Felt, Jeremy P. 1965. Hostages of Fortune: Child Labor Reform in New York State. Syracuse, N.Y.: Syracuse University Press.

Fine, Sidney. 1956. Laissez-Faire and the General-Welfare State: A Study of Conflict in American Thought. Ann Arbor: University of Michigan Press.

Forbath, William E. 1985. The Ambiguities of Free Labor: Labor and the Law in the Gilded Age. Wisconsin Law Review 1985:767-817.

1991. Law and the Shaping of the American Labor Movement. Cambridge, Mass.: Harvard University Press.

Friedman, Lawrence M. 1965. Freedom of Contract and Occupational Licensing 1890-1910: A Legal and Social Study. California Law Review 53:487-534.

1967. Government and Slum Housing: A Century of Frustration. Madison: University of Wisconsin Press.

Gillman, Howard. 1993. The Constitution Besieged: The Rise and Demise of Lochner Era Police Power Jurisprudence. Durham, N.C.: Duke University Press.

Gordon, Linda. 1988. Heroes of Their Own Lives: The Politics and History of Family Violence, Boston 1880-1960. New York: Penguin Books.

- ed. 1990. Women, the State, and Welfare. Madison: University of Wisconsin Press.

Hall, Kermit. 1989. The Magic Mirror: Law in American History. New York: Oxford University Press.

Harris, Cheryl. 1993. Whiteness as Property. Harvard Law Review 106:1707-91.

Harris, Neil. 1973. Humbug: The Art of P. T. Barnum. Chicago: University of Chicago Press.

Hartog, Hendrick. 2000. Man and Wife in America: A History. Cambridge, Mass.: Harvard University Press.

Horwitz, Morton. 1977. The Transformation of American Law, 1780-1860. Cambridge, Mass.: Harvard University Press. 
1992. The Transformation of American Law, 1870-1960. New York: Oxford University Press.

Hull, N. E. H. 1997. Roscoe Pound and Karl Llewellyn: Searching for an American Jurisprudence. Chicago: University of Chicago Press.

Hurst, James Willard. 1956. Law and the Conditions of Freedom in the Nineteenth Century United States. Madison: University of Wisconsin Press.

Jacobs, Clyde. 1954. Law Writers and the Courts: The Influence of Thomas Cooley, Christopher G. Tiedeman, and John F. Dillon upon American Constitutional Law. Berkeley and Los Angeles: University of California Press.

Kalman, Laura. 1986. Legal Realism at Yale, 1927-1960. Chapel Hill: University of North Carolina Press.

Keller, Morton. 1977. Affairs of State: Public Life in Late Nineteenth Century America. Cambridge, Mass.: Harvard University Press.

- 1990. Regulating a New Economy: Public Policy and Economic Change in America, 1900-1933. Cambridge, Mass.: Harvard University Press.

Kens, Paul. 1990. Judicial Power and Reform Politics: The Anatomy of Lochner v. New York. Lawrence: University Press of Kansas.

LaPiana, William. 1994. Logic and Experience: The Origins of Modern American Legal Education. New York: Oxford University Press.

Les Benedict, Michael. 1985. Laissez-Faire and Liberty: A Re-evaluation of the Meaning and Origins of Laissez-Faire Constitutionalism. Law and History Review 3:293-331.

Lindgren, Linda. 1983. Beyond Cases: Reconsidering Judicial Review. Wisconsin Law Review 1983:583-638.

Lubove, Roy. 1962. The Progressives and the Slums: Tenement House Reform in New York City 1890-1917. Pittsburgh: University of Pittsburgh Press.

Markel, Howard. 1997. Quarantine! East European Jewish Immigrants and New York City Epidemics of 1892. Baltimore: Johns Hopkins University Press.

McCormick, Richard L. 1979. From Realignment to Reform: Political Change in New York State 1893-1910. Ithaca, N.Y.: Cornell University Press.

McCurdy, Charles. 1975. Justice Field and the Jurisprudence of Government-Business Relations: Some Parameters of Laissez-Faire Constitutionalism, 1863-1897. Journal of American. History 61:970-1005.

1979. The Knight Sugar Decision of 1895 and the Modemization of American Corporation Law, 1869-1903. Business History Review 53:304-42.

Montgomery, David. 1987. The Fall of the House of Labor: The Workplace, the State, and American Labor Activism, 1865-1925. New York: Cambridge University Press.

Nelson, William E. 1982. The Roots of the American Bureaucracy 1830-1900. Cambridge, Mass.: Harvard University Press.

1988. The Fourteenth Amendment: From Political Principle to Judicial Doctrine.

Cambridge: Harvard University Press.

- 2001. The Legalist Reformation: Law, Politics, and Ideology in New York, 1920-1980. Chapel Hill: University of North Carolina Press.

Novak, William. 1996. The People's Welfare: Law and Regulation in Nineteenth Century America. Chapel Hill: University of North Carolina Press.

- 1999. The Legal Origins of the Modern American State. ABF Working Paper no. 9925. Chicago: University of Chicago and the American Bar Foundation.

Paul, Arnold M. 1960. Conservative Crisis and the Rule of Law: Attitudes of Bar and Bench, 1887-1895. Ithaca, N.Y.: Cornell University Press.

Pound, Roscoe. 1905. Do We Need a Philosophy of Law. Columbia Law Review 5:339-53. 
1912. The Scope and Purpose of Sociological Jurisprudence. Harvard Law Review 25:487-516.

Reid, John Phillip. 1995. Commentary: Beneath the Titans. NYU Law Review 70:653-76.

Riis, Jacob. [1890] 1971. How the Other Half Lives. New York: Dover Publications.

Rodgers, Daniel T. 1998. Atlantic Crossings: Social Politics in a Progressive Age. Cambridge, Mass.: Harvard University Press, Belknap Press.

Rosenberg, Charles E. 1987. The Care of Strangers: The Rise of America's Hospital System. New York: Basic Books.

Ross, William. 1994. A Muted Fury: Populists, Progressives, and Labor Unions Confront the Courts, 1890-1937. Princeton, N.J.: Princeton University Press.

Scheiber, Harry N. 1981. Regulation, Property Rights, and the Definition of "the Market": Law and the American Economy." Joumal of Economic History 41:103-9.

- 1984. Public Rights and the Rule of Law in American History. California Law Review 71:217-51.

1997. Book Review: Private Rights and Public Power: American Law, Capitalism, and the Republican Polity in Nineteenth-Century America. Yale Law Joumal 107:823-61.

Schlegel, John Henry. 1995. American Legal Realism and Empirical Social Science. Chapel Hill: University of North Carolina Press.

Sklar, Kathryn Kish. 1973. Catherine Beecher: A Study in American Domesticity. New Haven, Conn.: Yale University Press.

1995. Florence Kelley and the Nation's Work: The Rise of Women's Political Culture, 1830-1900. New Haven, Conn.: Yale University Press.

Smith, Franklin Abbott. 1952. Judicial Review of Legislation in New York, 1906-1938. New York: Columbia University Press.

Skocpol, Theda. 1990. Protecting Soldiers and Mothers: The Political Origins of Social Policy in the United States. Cambridge: Harvard University Press, Belknap Press.

Stanley, Amy Dru. 1998. From Bondage to Contract: Wage Labor, Marriage, and the Market in the Age of Slave Emancipation. New York: Cambridge University Press.

Tomes, Nancy. 1998. The Gospel of Germs: Men, Women, and the Microbe in American Life. Cambridge, Mass.: Harvard University Press.

Trinity Church. 1895. Report as to the Sanitary Condition of the Tenements of Trinity Church. New York: Evening Post Job Print House.

Twiss, Benjamin. 1942. Lawyers and the Constitution: How Laissez Faire Came to the Supreme Court. Princeton, N.J.: Princeton University Press.

Urofsky, Melvin. 1985. State Courts and Protective Legislation during the Progressive Era: A Reevaluation. Journal of American History 72:63-91.

Warren, Charles. 1913. The Progressives of the United States Supreme Court. Columbia Law Review 13:294-313.

1913. A Bulwark to the State Police Power-the United States Supreme Court. Columbia Law Review. 13:667-95.

White, Edward G. 2000. The Constitution and the New Deal. Cambridge, Mass.: Harvard University Press.

Wiebe, Robert. 1967. The Search for Order 1877-1920. New York: Hill and Wang.

Wiecek, William M. 1998. The Lost World of Classical Legal Thought: Law and Ideology in America 1886-1937. New York: Oxford University Press.

Witt, John Fabian. 2000. From Loss of Service to Loss of Support: The Wrongful Death Statutes, the Origin of Modern Tort Law, and the Making of the Nineteenth-Century Family. Law and Social Inquiry 25:717-56. 


\section{LAW \& SOCIAL INQUIRY}

\section{CASES}

American Rapid Telegraph Company ข. Hess, 125 N.Y. 641 (1891).

City of Rochester v. West, 164 N.Y. 510 (1900).

City of New York v. Chelsea Jute Mills, 88 N.Y.S. 1085 (1904).

Crossman v. Lurman, 171 N.Y. 329 (1902).

Health Department of New York v. Rector of Trinity Church, 17 N.Y.S. 510 (Ct. Common Pleas 1892).

Health Department of New York v. Rector of Trinity Church, 145 N.Y. 32 (1895).

In re Jacobs, 33 Hun. 382 (Sup. Ct. 1st Dept. 1884).

In re Jacobs, 98 N.Y. 98 (1885).

Lawton v. Steele, 119 N.Y. 226 (1890), aff'd, 152 U.S. 133 (1894).

Lochner v. New York, 177 N.Y. 145 (1904).

Lochner v. Neav York, 198 U.S. 45 (1905).

Muller v. Oregon, 208 U.S. 412 (1908).

Nechamcus v. Warden of the City Prison, 144 N.Y. 529 (1895).

New York ข. Arensberg, 105 N.Y. 123 (1887).

New York v. Bowen, 182 N.Y. 1 (1905).

New York v. Ewer, 141 N.Y. 129 (1894).

New York v. Girard, 145 N.Y. 105, 107 (1895).

New York ข. Hawnor, 149 N.Y. 195, 198 (1896).

New York v. Orange County Road Construction Company, 175 N.Y. 84 (1903).

New York थ. Rosenberg, 138 N.Y. 410 (1893).

New York ex rel. Lieberman v. Vandecarr, 175 N.Y. 440 (1903).

In re Paul, 94 N.Y. 497 (1884).

People ex rel. Kemp v. D'Oench, 111 N.Y. 359 (1888).

Ryan v. City of New York, 177 N.Y. 271 (1904).

Schnaier v. Navarre Hotel and Importation Company, 182 N.Y 83, 85 (1905).

Tenement House Department v. Moeschen, 179 N.Y. 325 (1904).

Tenement House Department v. Moeschen, 203 U.S. 583 (1906).

Tyroler v. Warden of the City Prison, 157 N.Y. 116 (1898).

Village of Cathage v. Frederick, 122 N.Y. 268 (1890). 